\title{
Evidence On The Effectiveness Of On-Line Homework
}

\author{
Jane Dillard-Eggers, Belmont University \\ Tommy Wooten, Belmont University \\ Brad Childs, Belmont University \\ John Coker, Belmont University
}

\begin{abstract}
The purpose of this research is to evaluate the impact and effectiveness of on-line homework in principles of accounting classes. We surveyed students to determine their degree of satisfaction with on-line homework and their perceptions about its effectiveness in enhancing their learning. We also gathered data to determine the extent of online homework completed and its effect on class performance. The results indicate that on-line homework increases student performance and that students believe that using on-line homework is an effective method of study.
\end{abstract}

Keywords: Home work, on-line homework, student performance

\section{INTRODUCTION AND MOTIVATION}

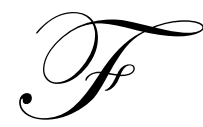

aculty members are continually integrating technology into their courses to attempt to deliver the course content more efficiently and to increase student learning. On-line, distant-learning courses that deliver class materials exclusively with the use of technology are now commonplace. However, the use of technology is not limited to only on-line courses. Many faculty teaching more "traditional" courses are using aspects of on-line technology to enrich their courses. Using on-line homework technology to assign problems, provide feedback, and determine grades for homework is one way to use technology to enrich the students' experiences in the course.

The use of on-line homework can benefit both students and faculty. Students have the ability to work problems and receive feedback at times convenient with their schedules. Also, through the use of computer algorithms, the software allows the students to increase the number of problems they work by having assigned problems that can be different each time. Lastly, because this generation of students has clearly embraced technology to a greater extent that their older peers, the ability to use the computer for homework may motivate students to do more homework than they normally would have done with pencil and paper.

Time-saving benefits also accrue to faculty who utilize on-line homework. Faculty members, in general, believe that homework is helpful to students and encourage them to complete homework problems. However, grading homework "by hand" requires a huge time commitment on the part of faculty. On-line homework problems can be assigned and graded with minimal faculty time. In addition, since students can receive instant assistance and feedback, less faculty time is needed to meet with students over small details related to homework. This time savings allows the faculty to spend more time on other classroom enhancing activities or other required duties.

Educators should consider and evaluate the effectiveness of this technology for increasing (or at least not harming) student learning. Accordingly, the purpose of this research is to evaluate the impact and effectiveness of on-line homework in principles of accounting classes. We surveyed students to determine their degree of satisfaction with on-line homework and their perceptions about its effectiveness in enhancing their learning. We also gathered data to determine the extent of online homework completed and its effect on class performance. The next section of this paper presents a review of the literature in this area and the development of our research 
questions. We then describe our study and present the results of our analysis. We close with a summary of major findings and conclusions based on those finding.

\section{SELECTED LITERATURE REVIEW AND RESEARCH QUESTIONS}

\section{Does Homework Make A Difference?}

As one would expect, multiple studies in the education field have examined the relationship between homework and performance. Cooper (1989) and Cooper et. al. (2006) document several meta-analysis on the effect of homework on academic achievement. Cooper (1989) reviewed 120 studies on homework from 1962 to 1986. Cooper et al. (2006) extended this research analyzing studies from 1987 to 2003. Both analyses concluded that there is evidence for a positive correlation between homework and achievement. Cooper (1989) reviewed 120 empirical studies of the effect of homework. He grouped the studies into three categories. The first group of studies compared students given homework assignment to students not given homework assignments. The second category of studies compared outside-of-class homework to in-class, supervised study. The third set of studies examined the relationship between the amount of time spent on homework and performance. All three categories of studies indicated that homework and the amount of time spent on homework are positively related to better performance.

\section{Does On-Line Homework Make A Difference?}

We next review literature that has examined the impact of on-line homework and feedback on performance. While the results have been mixed, it has generally been found that on-line homework has either no effect on student performance or increases student performance. Hauk and Segalla (2005) found that online homework was at least as effective as traditionally graded paper and pencil homework for students learning college algebra. Taraban et al. (2005) found that on-line homework usage in introductory thermodynamics courses correlated with exam scores. Cheng et al. (2004) found that on-line homework increased students' understanding on introductory physics in both interactive and non-interactive classroom environments. Positive results also are reported for online learning systems that included more than just homework preparation. For example, Potter and Johnston (2006) assessed their unique online teaching systems and found a correlation between system usage and performance.

One reason why on-line homework may be "better" than traditional homework is the availability of immediate feedback. Students immediately know whether they missed a question, thus allowing their thought processes to be corrected while the mistake is still fresh. Students then have the capability to work additional, similar problems until they master the concept. Again, studies have been mixed, but there is indirect evidence that feedback can have a positive impact on learning. Biktrimirov and Klassen (2005) found a positive relationship between student performance and access to solutions. On the other hand, Lindquiest and Olsen (2007) found that providing students with homework solutions, no solutions, or check figures did not impact students' test scores. Providing solutions or check figures did, however, increase their perception of learning and satisfaction with their final course grade. Additionally, students who did not receive solutions or check figures were least satisfied with their assistance and reported greater frustration over homework.

\section{Research Questions}

Based on these consistent findings of a positive relationship between homework and performance, we propose the first research question.

Research Question One: Does the amount of homework done (online homework in this case) impact the students' performance in the course?

If research question one is true, it seems appropriate for educators to encourage students to use homework as a tool to increase understanding and performance. Thus, if educators can use on-line technology to encourage homework and to more efficiently manage the assignment and grading of homework, then this technology should be 
embraced. Given the ease at which the current generation embraces technology, it is possible that the use of technology will encourage students to study more. However, if the technology is difficult to use, or it is poorly accessible, it may encourage less studying. Thus, our second and third research questions deal with student motivation and their perception of the ease of use.

Research Question Two: Does the use of on-line homework impact the amount of time spent studying?

Research Question Three: Did students perceive the homework software as difficult from a technical standpoint?

The following research questions further assess the students' perceptions of the benefits of on-line homework.

Research Question Four: Does online homework have a positive impact on the quality of study time?

Research Question Five: Does online homework have a positive impact on understanding of the topics and problems?

Research Question Six: Overall, how do you rate your experience using on-line homework?

Research Question Seven: Is online homework more beneficial than traditional paper and pencil homework?

\section{METHODOLOGY}

We surveyed 233 students in 8 accounting principles classes that were taught by four different instructors. In all of these classes students had access to on-line homework problems. For 149 of the students, on-line homework was a required part of the course grade. In the other classes homework problems were identified and only recommended for exam preparation; homework was not a separate required part of the course grade.

We were able to determine the extent to which students completed homework using information compiled within the on-line homework program. Because the students provided their name on the survey we were also able to link the completion of homework to course grade. We asked students for their perceptions on the use of on-line homework. They responded to specific questions using a Likert scale and provided more information in response to open-ended questions. To better understand our student respondents we also obtained permission from the students to gather demographic information from student records.

Fifty-five percent of the students who completed our survey were male while $45 \%$ were female. They ranged in age from 18 to 59 with an average age of 20.9. The average ACT score for our student participants was 24.7 and the average SAT score was 1128. Our student participants had an average overall GPA of 3.2 and were carrying a course load of from 3 to 20 hours (average 15) during the semester of our study. We discuss some interesting correlations between particular demographic information and survey responses later in the results section of the paper.

\section{RESULTS}

\section{Regression}

We used regression analysis to investigate research question one, the impact of homework on performance. We used the covariate Prior GPA to adjust the dependent variable Course Grade for a measure of the expected grade in the class. Our independent variable is Homework Score, the number of problems worked correctly in the on-line homework program. Specifically, our research model is: 


\section{COURSE GRADE = F (PRIOR GPA, HOMEWORK SCORE)}

We show the results of our regression analysis in Table 1 . The model is significant at $p=.000$, with an adjusted $\mathrm{R}^{2}$ of .533 . The covariate, Prior GPA, is significant at $\mathrm{p}=.000$ and Homework Score is significant at $\mathrm{p}=.001$. Thus, we conclude that the course grade (after adjusting for Prior GPA) was positively affected by the extent of work on on-line homework. (Note: We also ran these statistics controlling for whether the homework was required or not required and the results did not change significantly). Our results support earlier findings for the positive impact of homework on performance.

\section{Survey Responses}

Our other research questions are concerned with the impact of on-line homework in particular rather that the impact of homework in general. To investigate these issues we gather information from students regarding their use of on-line homework and their perceptions of its effectiveness. In Table 2 we compile the students' responses to our survey questions.

Research question two asks if the use of on-line homework impacts the amount of time spent studying. We found that $44 \%$ of students spent about the same amount of time studying, while $39 \%$ indicated that they spent more, and only $16 \%$ spent less time. So, for some (although not a majority) the ability to study on-line motivated them to spend more time.

As noted in research question three, students' perceptions of the benefit of on-line homework would certainly be impacted to the extent they experienced technical difficulties while using the program. So, we first asked students to what extent they had experienced technical problems while using the on-line homework program. Only $5 \%$ of the students indicated that they had some/many problems, while $69 \%$ responded that they had few or no problems. Thus, we conclude that technical problems should not significantly impact students' perceptions of the benefits of on-line homework in general.

Students can also differentially benefit from on-line homework if the quality of their study time is enhanced in some way by the use of the on-line technology. Research questions four, five, and six address the issues of the quality and effectiveness of study time. In response to research question four, 53\% of student respondents perceived that the use of on-line homework resulted in higher quality of study time compared to alternative methods, while only $15 \%$ believed that their on-line study time was of less quality. For research question five, 55\% of students thought that the use of on-line homework resulted in a higher understanding of the topics and problems as compared to alternative methods, while only $12 \%$ thought that their level of understanding was less. Students were also asked to provide an overall rating of their experience with on-line homework. We expect this question to encompass issues such as comfort with the technology, convenience of the on-line format along with the quality of their study time. In response to research question six and consistent with the rating on the other scales, $54 \%$ of students rated their experience with on-line homework as good, while only $10 \%$ rated the experience as bad.

Research question seven asks students to directly compare on-line homework with the more traditional "pencil and paper" homework with respect to its impact on learning. The responses to this question reveal more divergent opinions regarding the benefits of on-line technology. While 49\% thought on-line homework was better with respect to learning, $31 \%$ thought that its effect on learning was worse compared to the "pencil and paper" alternative. We believe this response indicates that, while the vast majority of students seem to be able to adapt to on-line computer-based assignments, some would prefer to continue to do homework and study the "old" way. We question whether this response may be related to the age of the student; whether older students may prefer the "low tech" method of doing homework.

We used correlation analysis to investigate the relationship between the age of the student on students' perceptions of on-line homework. We find a marginally significant negative relationship between the age of the student and the perceived benefits of on-line compared to "pencil and paper" homework ( $p=.059)$. Interestingly, we 
also found that older students reported significantly lower levels of understanding of topics and problems with online homework $(\mathrm{p}=.011)$ and provided lower overall ratings of the on-line homework experience $(\mathrm{p}=.025)$.

When we further examined the relationship of student demographic information to the amount of homework done we found that older students and students taking fewer credit hours completed more homework $(\mathrm{p}=.039$ and $\mathrm{p}=.029$, respectively). We also found a significant negative relationship between the age of the students and the number of credit hours taken $(\mathrm{p}=.010)$. Older students also reported significantly lower ACT and SAT scores $(\mathrm{p}=.035$ and $\mathrm{p}=.000$, respectively) These results portray a diverse student group with different levels of preparation and different abilities. Thus, we conclude that generalizations regarding the benefits of technological enhancements are difficult to make because different students may react in different ways.

\section{Responses To Open-Ended Questions}

To better understand the students' responses to our survey questions, we also asked open-ended questions regarding the students' experience; specifically what they liked best and liked least about on-line homework. Table 3 lists the items that were most frequently cited by students. As expected, students liked the immediate feedback and fact that the homework program was somewhat interactive and gave hints to the students when their initial responses were incorrect. They commented on the ease of use and their preference for typing rather than writing. On-line homework tended to provide more structure to the problems compared to sitting down with a blank sheet of paper. Students liked being forced or motivated to do the work (possibly students liked homework being required for course grade, or students felt more motivated to sit down before the computer rather than with just pencil and paper).

The problem with on-line homework most commonly cited by students was confusion with the answer format. For example, a student's answer would show as incorrect if they did not show the expected number of decimal points. Students' expressed their dislike for hints that were unhelpful for them. Some students experienced technical problems; while others felt that the assigned problems and on-line solutions were too simple (possibly not reflective of the complexity of the topic). Students noted errors in the program and inconsistencies between the homework and the class notes and tests. Some simply stated that they preferred the "pencil and paper" alternative.

\section{SUMMARY AND CONCLUSIONS}

Consistent with earlier research we found that course grade (adjusted for prior GPA) was positively affected by the extent of homework done. With respect to the benefits of on-line homework in particular, we found that less than half of the respondents indicated that they spent more time studying because of the on-line format. However, a clear majority of students believed that the on-line format was beneficial in other ways. Fifty-three percent believed that the use of on-line homework increased the quality of their study time and 55\% believed that it led to a greater understanding of the topics and problems. Despite these positive perceptions of the benefits of online homework technology, a large percentage (31\%) felt that "pencil and paper" homework would lead to greater learning. We think this is indicative of a diverse student population, with different experiences, skills and abilities, and also different learning styles. Our study particularly identifies differences in perceptions and abilities based on the age of the student. Future studies to more fully explore the differential impact of technology on diverse student populations would greatly add to our overall understanding of the benefits of technology on learning.

\section{REFERENCES}

1. Biktmirov, E.N. and K.J. Klassen. (2005) Relationship between the use of online support materials and performance in the introductory finance class. Forthcoming Journal of Education for Business.

2. Cheng, K.K., B.A. Thacker, R.L. Cardenas, C. Crouch. (2004) Using an online homework systems enhances students' learning of phsycis concepts in an introductory physics course. American journal of physics. November, 27,11, 1447.

3. Cooper, H. (1989). Homework. White Plains, NY: Longman. 
4. Cooper, H., J. C. Robinson, and E.A. Patall. (2006). Does homework improve academic achievement? A synthesis of research, 1987-2003. Review of Educational Rsearch, spring, 76,1,1-62.

5. Hauk, S., A. Segalla. 2005. Student perceptions of the web-based homework program WeBWorK in moderate enrollment college algebra classes. Journal of computers in mathematics and science teaching 24, 3, 229-253.

6. Lindquist, T.M., L.M. Olsen (2007). How much help, is too much help? An experimental investigation of the use of check figures and completed solutions in teaching intermediate accounting. Journal of accounting education, 25, 3, 103.

7. Potter. B.N., C.G. Johnston. (2006) The effect of interactive on-line learning systems on student learning outcomes in accounting. Journal of accounting education. 24,1,16.

8. Taraban, R., E.E. Anderson, M.W. Hayes, and M.P. Sharma. 2005. Developing on-line homework for introductory thermodynamics. Journal of engineering education. July, 94, 3. 339-342.

Table 1

Regression Analysis

\begin{tabular}{|c|c|c|c|c|c|}
\hline Factor & Sum of Squares & df & Mean Square & F-Stat & p-value \\
\hline Corrected Model & 1581.846 & 145 & 10.909 & 2.827 & .000 \\
\hline Intercept & 39.387 & 1 & 39.387 & 10.206 & .002 \\
\hline Prior GPA & 306.170 & 1 & 306.170 & 79.333 & .000 \\
\hline Homework Score & 1021.738 & 144 & 7.095 & 1.839 & .001 \\
\hline Error & 335.760 & 87 & 3.859 & & \\
\hline Total & 21371.000 & 233 & & & \\
\hline
\end{tabular}

$\mathrm{R}^{2}=.825 ;$ Adjusted $\mathrm{R}^{2}=.533$

Table 2

Percent of students' responses to each item

\begin{tabular}{|c|c|c|c|}
\hline Research question Two & Much more & & Much less \\
\hline $\begin{array}{l}\text { How do you think the use of on-line homework affected the amount of time } \\
\text { you spent studying compared to alternative methods? }\end{array}$ & $39 \%$ & $44 \%$ & $16 \%$ \\
\hline Research question Three & No problems & \multicolumn{2}{|c|}{ Many problems } \\
\hline $\begin{array}{l}\text { To what degree did you experience technical problems while using the on- } \\
\text { line homework program? }\end{array}$ & $69 \%$ & $33 \%$ & $5 \%$ \\
\hline Research question Four & \multicolumn{2}{|l|}{ Much higher } & Much lower \\
\hline $\begin{array}{l}\text { How do you think the use of on-line homework affected the quality of your } \\
\text { study time compared to alternative methods? }\end{array}$ & $53 \%$ & $32 \%$ & $15 \%$ \\
\hline Research question Five & \multicolumn{2}{|l|}{ Much higher } & Much less \\
\hline $\begin{array}{l}\text { How do you think the use of on-line homework affected your understanding } \\
\text { of the topics and problems compared to alternative methods? }\end{array}$ & $55 \%$ & $33 \%$ & $12 \%$ \\
\hline Research question Six & \multicolumn{2}{|l|}{ Very good } & Very bad \\
\hline Overall, how would you rate your experience using on-line homework? & $54 \%$ & $36 \%$ & $10 \%$ \\
\hline Research question Seven & \multicolumn{2}{|l|}{ Much better } & Much worse \\
\hline $\begin{array}{l}\text { With respect to learning, how does the use of on-line homework compare to } \\
\text { "pencil and paper" homework? }\end{array}$ & $49 \%$ & $20 \%$ & $31 \%$ \\
\hline
\end{tabular}


Table 3

What Students Liked Best and Liked Least About On-line Homework

\begin{tabular}{|cl|}
\hline \multicolumn{2}{|l|}{ Liked Best } \\
\hline 1. & Unlimited attempts and knowing if it is correct right away \\
\hline 2. & You receiving hints if you missed the answer \\
\hline 3. & Ease of use \\
\hline 4. & Were able to type instead of write \\
\hline 5. & It gave structure to the problem \\
\hline 6. & Problems were related to class/teacher/book \\
\hline 7. & It either forced or motivated me to do homework \\
\hline \multicolumn{2}{|l|}{} \\
\hline Liked Least \\
\hline 1. & There was confusion with the answer format \\
\hline 2. & The hints were too vague to be helpful \\
\hline 3. & Experienced technical problems \\
\hline 4. & Homework was too simple \\
\hline 5. & There were inconsistencies between homework and test/class notes \\
\hline 6. & Errors in the homework compared to the text \\
\hline 7. & I would forget to do the assignments \\
\hline 8. & I like using pencil and paper better \\
\hline 9. & Homework system was too slow. \\
\hline
\end{tabular}


NOTES 